\title{
A Comparative Study of Using Students Team Achievement Division (STAD) and Three Minutes Review (TMR) Strategies in Teaching Questions
}

\author{
Endah Fauziningrum \\ STIMART AMNI \\ Jl. Soekarno-Hatta no. 180 Semarang \\ endahfauziningrum@yahoo.com
}

\begin{abstract}
The objective of this research was to find out the effectiveness of using STAD and TMR strategies to teach questions to the third grade of elementary school students. The data of the research were taken in Sompok state elementary school 03 and 04 . The research design used was factorial design. It means that the writer had two groups, one was taught by using STAD strategy and the other was taught by using TMR strategy. STAD and TMR strategies had two sub-divisions, students who take English courses and students who do not take English courses. The number of the research sample for each cell was 12 students. There were four time lesson of periods for STAD and TMR classes. To investigate the effectiveness of using STAD and TMR strategies, the writer used Ftest formula. The results were: 1) STAD was effective to teach question to students who take English courses. It was showed from the pre-test (10.83) and the post-test (12.75). 2) STAD was effective to teach question to students who do not take English courses. It was shown on the mean of pre-test (8.58) and the post-test (11.25). 3) TMR was effective to teach question to students who take English courses. It was shown on the mean of pre-test (10.67) and the post-test (11.50). 4) TMR was effective to teach question to students who do not take English courses. It was shown on the mean of pre-test (9.83) and post-test
\end{abstract}


(10.42). There was not any interaction between the students who take English courses and who do not and and who were taught by using STAD and TMR atrategies.it showed from the ANOVA result. The result was the interaction between strategies and taking courses variables showed 0.325 with sig 0.571 . Since, sig $0.571>0.05$, then the interaction between strategies and taking courses variables do not effect the students achievement.

Key words: Comparison, Third Grade Elementary School Students, STAD Strategy, TMR Strategy, the Effectiveness of Using Teaching Strategy

\section{Abstrak}

Tujuan dari penelitian ini adalah untuk mengetahui efektivitas penggunaan strategi STAD dan TMR untuk mengajarkan pertanyaan ke kelas tiga siswa sekolah dasar. Data penelitian diambil di SD Negeri 03 dan 04 Sompok. Desain penelitian yang digunakan adalah rancangan faktorial. Ini berarti bahwa penulis memiliki dua kelompok, satu diajarkan dengan menggunakan strategi STAD dan yang lainnya diajarkan dengan menggunakan strategi TMR. Strategi STAD dan TMR memiliki dua sub-divisi, siswa yang mengambil mata kuliah bahasa Inggris dan siswa yang tidak mengambil kursus bahasa Inggris. Jumlah sampel penelitian untuk setiap kelompok adalah 12 siswa. Ada empat jam pelajaran untuk kelas STAD dan TMR. Untuk meneliti efektivitas penggunaan STAD dan TMR strategi, penulis menggunakan rumus F test. Hasilnya: 1) STAD efektif untuk mengajar pertanyaan kepada siswa yang mengambil kursus bahasa Inggris. Hal ini dilihat dari pre-test $(10,83)$ dan post-test $(12,75)$. 2) STAD efektif untuk mengajar pertanyaan kepada siswa yang tidak mengambil kursus bahasa Inggris. Hal ini ditunjukkan pada rata-rata pre -test $(8,58)$ dan post-test $(11,25)$. 3) TMR efektif untuk mengajar pertanyaan kepada siswa yang mengambil kursus bahasa Inggris. Hal ini ditunjukkan pada rata-rata pre test $(10,67)$ dan post-test $(11,50)$. 4) TMR efektif untuk mengajar pertanyaan kepada siswa yang tidak mengambil kursus bahasa Inggris. Hal ini ditunjukkan pada rata-rata pre -test $(9,83)$ dan post-test $(10,42)$. Tidak ada interaksi antara siswa yang mengambil kursus bahasa Inggris dam yang tidak dan yang diajar dengan menggunakan strategi STAD dan TMR. Hal ini diperoleh dari hasil ANOVA. Hasilnya adalah interaksi antara strategi dan variabel mengikuti kursus menunjukkan 0,325 dengan 
sig 0.571. Karena, sig $0.571>0.05$, maka interaksi antara strategi dan variabel mengikuti program tidak mempengaruhi prestasi belajar siswa.

Kata Kunci : Perbandingan, Siswa SD Kelas Tiga, Strategi STAD, Strategi TMR, Efektivitas Penggunaan Strategi

Pengajaran

\section{Introduction}

KTSP curriculum or School Based Competence Curriculum concerning elementary schools stated that English is the first foreign language taught in elementary schools. English as a local content subject in an elementary school aims at introducing English as the first foreign language to students. The benefit of studying English for the students is to introduce the basic skill of English, so that they will be well prepared in learning English as a preparation for the higher level of education.

The English instruction in the elementary school is intended to endorse the mastery and development of the four basic skills, they are, listening, speaking, reading and writing as reflected in skills concerning language use so that the students are able to express simple expression with emphasis on question mastery. In order to attain better outcomes, the teacher should choose an appropriate teaching strategy, which is suitable with the subject matter in teaching learning process. Teachers need to choose instructional strategy which will be able to help students to improve their English basic skills.

The students sometimes find that English teaching and learning process in the classroom is boring. It is because the teacher still had the traditional ways of teaching that their role are as instructors and 
knowledge transmitters. Because of this, few classroom activities are learner centered. Some methods teachers' used ignoring the learners, potentials and resources; therefore, teachers should find a way to make the teaching and learning English more meaningful. Therefore, the students can understand the lesson easily.

According to Tseng $(2005: 10)$ there are some factors affecting students' success in class. The factors are such as; the material level of difficulty, the kinds of activity used, the mood of the classroom, the classmates support, and the teacher's encouragement. These factors can certainly play a large role in influencing the students' motivation in learning English.

The teachers' decisions in structuring lesson can influence students' interaction with others, knowledge, and attitudes (Carson, 1991; Johnson and Johnson, 1987:37). In making this decision, teachers should choose carefully a method that appropriate to both students and the subject.

Cooperative learning is an instructional methodology where students work together to attain group goals that cannot be obtained by working individually or competitively. In this classroom design, students discuss the certain subject, help each other, learn together, and provide encouragement for member of the group.

Cooperative learning, as an instructional method provides opportunities for students to develop skills in-group interactions and in working with others that are needed in today world (Carol, 1988; Imel, 1989; Kerka, 1990:7). According to Johnson and Johnson (1989:21), cooperative learning experiences promote more positive attitudes toward the instructional experience than competitive or individualistic 
methodologies. In addition, cooperative learning should result in positive effect on student achievement and retention of information (Dishon and O’Leary, 1984; Johnson and Johnson, 1990; Slavin, 1991:17). According to McKeachie (1986:14), students are more likely to acquire critical thinking skills and metacognitive learning strategies, such as learning how to learn in small cooperative group setting opposed to listening to lectures.

While cooperative learning as an instructional method is an option for teachers, it is currently the least frequently used (Johnson and Johnson, 1991:12). More than 85\% of the instructions in schools consist of lectures, seatwork, or competition in which students are isolated from one another and forbidden to interact (Johnson, Johnson, Holubec, and Roy 1984:38). Goodlad (1984:70) reported that most classroom time is spend in "teacher talk", with only $1 \%$ of the students classroom time used for reasoning about or expressing an opinion.

Third grade students are the first students that will receive a standardized test from the government. In the test, mostly, a question will be followed with a picture. This picture is expected to help the students to understand the question. However, the picture sometime misdirects the students. This misdirection causes the students' misunderstanding the question. The students' lack of understanding causes the questions used in the test have not explained clearly.

The fact that the demand of mastering English is getting higher, students have to study hard, either at school or at home. However, sometimes studying hard is not enough, it makes the students looking for additional way out to fulfill the demand. Taking English courses is likely the best decision. 
Taking courses will effect on the students achievement is on most students' mind. It means that if a student takes English courses, the student will gain more understanding on the subject and this, will lead to good score. While, other student that does not take an English course will only get enough score because of their lack of understanding about the subject. However, taking English courses need money and time to sacrifice and not all students can afford it. That is why, teachers should choose an appropriate teaching strategy.

The writer chooses Student Teams Achievement Division (STAD) and Three Minutes Review (TMR) strategies to teach question words to the third grade student because the demand of creativity and cooperative from the student. Moreover, those strategies are fun. Moreover, it is expected to help the students to understand questions.

STAD and TMR are strategies that require students to work in a team to understand and to solve a problem, in this case to understand the questions in English. These two strategies demand students' creativity and cooperation because both require students work with other students that probably do not have the same level of competence, they have to work together so that all the member of the group will understand. "cooperative goal structure creates a situation in which the only way group members can attain their personal goals is if the group is successful (Slavin, 2007:52). Therefore, in order to attain their personal goals, students are encourage members within the group to do whatever it needs to help the group to succeed and help one another with a group task.

The purposes of the research are to identify the effectiveness of teaching questions using STAD and TMR strategies to the students who 
take and do not take English courses. Other purposes are to identify the difference of the questions mastery of the students taught using STAD and TMR strategies and to identify the interaction between the students.

\section{STAD strategy}

Student Teams-Achievement Divisions (STAD) in Student Teams-Achievement Divisions (STAD) (Slavin, 2007:20), students are assigned to four-member learning teams that are mixed in performance level, gender, and ethnicity. The teacher presents a lesson, and then students work within their teams to make sure that all team m embers have mastered the lesson. Finally, all students take individual quizzes on the material, at which time they may not help one another.

Students' quiz scores are compared to their own past averages, and points are awarded on the basis of the degree to which students meet or exceed their own earlier performance. These points, then summed to form team scores, and teams that meet certain criteria may earn certificates or other rewards.

The STAD strategy is most appropriate for teaching well-defined objectives with single right answers, such as mathematical computations and applications, language usage and mechanics, geography and map skills, and science facts and concepts. However, it can easily be adapted for use with less well-defined objectives by incorporating more openended assessments, such as essays or performances (Slavin, 2005:15).

\section{TMR strategy}

Three Minutes Review strategy is a strategy in which teacher may stop any time during a lecture or discussion and give teams three minutes 
to review what has been said, asking clarifying questions or answering questions. The teacher randomly selects the group to clarify or answer questions.

The students will do a test individually and the score will be the team score. This is by adding all the member of the group score then dividing them according to the number of the member.

\section{Null hypothesis}

The null hypothesis is a statement that you want to test. In general, the null hypothesis is that things are the same as each other, or the same as a theoretical expectation. And the alternative hypothesis is that things are different from each other, or different from a theoretical expectation. The null hypothesis of this research are as follow:

Table 1

Null Hypothesis

\begin{tabular}{|l|l|l|}
\hline & In Symbols & \multicolumn{1}{|c|}{ In Words } \\
\hline B1 & $\mu_{\mathrm{B} 1}$ & $\begin{array}{l}\text { STAD is not effective to teach questions to } \\
\text { students who take courses }\end{array}$ \\
\hline B1 & $\mu_{\mathrm{B} 1}$ & $\begin{array}{l}\text { STAD is not effective to teach questions to } \\
\text { students who do not take courses }\end{array}$ \\
\hline B2 & $\mu_{\mathrm{B} 2}$ & $\begin{array}{l}\text { TMR is not effective to teach questions to } \\
\text { students who take courses }\end{array}$ \\
\hline B2 & $\mu_{\mathrm{B} 2}$ & $\begin{array}{l}\text { TMR is not effective to teach questions to } \\
\text { students who do not take courses }\end{array}$ \\
\hline A1 & $\mu_{\mathrm{A} 1}$ & $\begin{array}{l}\text { Students who take courses do not have good } \\
\text { score }\end{array}$ \\
\hline A2 & $\mu_{\text {A2 }}$ & $\begin{array}{l}\text { Students who do not take courses do not have } \\
\text { good score }\end{array}$ \\
\hline
\end{tabular}

In this thesis, the writer uses the alternative hypothesis because finding the effectiveness of a strategy might lead to all kinds of exciting 
discoveries about teaching strategy to the third grade of elementary school students especially on using it to teach English.

\section{Research methodology}

\section{Research variables}

This study includes 2 variables. There are independent variable and moderator variable. The independent variables are the STAD and TMR strategies. And, the moderator variables are students who taking English courses and students who do not taking English courses.

\section{Research Design}

This is an experimental research. In this case, the research design is factorial design. Factorial design is a modification of a true experimental design, with the further complication that additional independent variables (usually moderator variables) are included in addition to the treatment variable.

In factorial designs, a factor is a major independent variable. In this experiment, we have two factors: students taught using STAD strategy and students taught using TMR strategy. A level is a subdivision of a factor. STAD strategy has two levels and TMR strategy has two levels. Sometimes we depict a factorial design with a numbering notation. We can say that we have a 2 x 2 (spoken "two-by-two) factorial design. The diagram is as follow:

Table 2

Factorial Design

\begin{tabular}{|l|l|l|l|}
\hline & $\begin{array}{c}\text { Students who take } \\
\text { courses }(\mathrm{A} 1)\end{array}$ & $\begin{array}{c}\text { Students who don't } \\
\text { take courses }(\mathrm{A} 2)\end{array}$ & Total \\
\hline STAD & $\mu_{\mathrm{A} 1 \mathrm{~B} 1}$ & $\mu_{\mathrm{A} 2 \mathrm{~B} 1}$ & $\mu_{\mathrm{B} 1}$ \\
\hline
\end{tabular}




\begin{tabular}{|l|l|l|l|}
\hline$(\mathrm{B} 1)$ & & & \\
\hline TMR $(\mathrm{B} 2)$ & $\mu_{\mathrm{A} 1 \mathrm{~B} 2}$ & $\mu_{\mathrm{A} 2 \mathrm{~B} 2}$ & $\mu_{\mathrm{B} 2}$ \\
\hline Total & $\mu_{\mathrm{A} 1}$ & $\mu_{\mathrm{A} 2}$ & \\
\hline
\end{tabular}

\section{Population and sampling}

In this research, the writer used sample because SDN Sompok is a school group comprising of SDN Sompok 01, SDN Sompok 02, SDN Sompok 03 and SDN Sompok 04. The writer conducted the experiment on the third grade students of SD N Sompok 03 and SD N Sompok 04 because those classes had similarity in number and students joining English courses than other classes. The group that followed English courses in both STAD and TMR classes and the non-taking English courses was divided in to smaller groups. A group of four students were established, but not all groups were examined. The writer only examined three groups from each variable as the sample.

\section{Try out of the instrument}

Before the instrument is applied the sample of the study the validity and reliability of instrument shall be tasted. To know whether the instrument is applicable it is tested in try out. The try out was given to respondent out of the subjects of the research. The try out result was used to test the validity and reliability of the instrument. The try out instrument was on multiple-choice form with 15 numbers of questions.

\section{Validity}

Pearson states that an item will have a high validity of the item score if it has parallelism or correlation with total score. The formula applied to know the item validity is the correlation formula.

$$
\operatorname{rxy}=\quad \sum x y-\left(\sum x\right)\left(\sum y\right)
$$




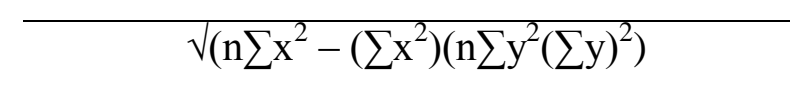

\section{Reliability}

Heaton (1979: 156) states that in order to be reliable a test must be consistent in its instrument. This formula applied in order to discover the interval reliability of each test.

$$
\mathrm{R}_{11}=\frac{(k)\left(\mathrm{s}^{2}-\sum \mathrm{pq}\right)}{K-1 \mathrm{~s}^{2}}
$$

A standardized test must have a reliability measurement of at lest 0,80 (Heaton, 1979:157)

\section{Procedure of collecting data}

Test of homogeneity

This test is conducted to know whether the score of one group has homogenous variants with the score of the other group or not using Levene's test.

The test statistic, $W$, is defined as follows:

$$
\begin{aligned}
W= & \frac{(N-k)}{(k-1)} \frac{\sum_{i=1}^{k} N_{i}\left(Z_{i .}-Z . .\right)^{2}}{\sum_{i=1}^{k} \sum_{j=1}^{N_{i}}\left(Z_{i j}-Z_{i .}\right)^{2}}, \\
& \left(\left[\text { accessed on Feb }, 4^{\text {th }}\right]\right)
\end{aligned}
$$

Levene's test does not require normality of the underlying data. Levene's test of homogeneity of variance test the ANOVA assumption that each group (category) of the independent)(s) has the same variance. If the Levene statistic is significant at the .05 level or better, the researcher rejects the null hypothesis that the groups have equal 
variances. The Levene test is robust in the face of departures from normality. Note, however, that failure to meet the assumption of homogeneity of variances is not fatal to ANOVA, which is relatively robust, particularly when groups are of equal sample size.

Hypothesis testing

The $F$-test is used to test for differences among sample variance. The formula for $F$ is simply

$$
F=\frac{s_{1}^{2}}{s_{2}^{2}}
$$

The variance are arranged so that $F>1$. That is; $s_{1}{ }^{2}>s_{2}{ }^{2}$. The writer uses the $F$-test as the Student's $t$ test in testing significant differences in the variances.

\section{Discussions}

\section{Validity}

To find out the validity of the pre-test and the post-test the writer used Pearson product moment formula. It is used to discover the valid items by consulting to the R-table, because the writer conducted the try out to 20 students, it means each item has to have more than 0.444 score point to be said valid.

After calculating the validity test using SPSS 17.0, there are 14 valid items out of 15 items, and 1 out of 15 items is considered to be invalid because it has score point under 0.444 .

\section{Reliability}

The criterion of reliability provides information on whether the data collection procedure is consistent and accurate. To discover the internal reliability of each test the KR-20 formula is applied. 


$$
\begin{aligned}
& \text { Reliability Coefficients } \\
& \mathrm{N} \text { of Cases }=20,0 \\
& \mathrm{~N} \text { of Items }=15 \\
& \text { Alpha }=, 8918
\end{aligned}
$$

The statistic description above showed that the result of the reliability test is 0.8918 . Since, the data is said to be reliable if the result is at least 0.80. From the data above the score is $0.8918>0.80$. Therefore, it can be said that the data is reliable.

\section{Homogeneity test of try out sample}

Homogeneity test is used to analyze the homogeneity of the population. This test uses Levene's test formula. The result is as follows:

Table 8

\begin{tabular}{|c|c|c|c|}
\hline$F$ & df1 & $\mathrm{d} 2$ & Sig. \\
\hline 1,053 & 3 & 44 &, 379 \\
\hline
\end{tabular}

The Result of Try Out Homogeneity Test

$$
\text { Levene's Test of Equality of Error Variances a }
$$

Dependent Variable: Prestasi Belajar

Tests the null hypothesis that the err or variance of the dependent variable is equal across groups.

a. Design: Intercept+METHOD+COURSE+METHOD * COURSE $A$ population can be categorized homogenous if the $F$ value is higher than 0.05 . As shown in the table above that the $\mathrm{F}$ value is $1.053>$ 0.05 with the significant (sig) 0.379 . Therefore, it can be said that the tryout sample population is homogenous.

\section{Homogeneity test of Research Sample}


This is the result of homogeneity test for research sample of STAD and TMR strategies.

Table 10

The Result of Research Sample Homogeneity Test

\begin{tabular}{|r|r|r|r|}
\hline \multicolumn{4}{|c|}{ Prestasi Belajar (Learning achievement) } \\
\hline Levene Statistic & Df1 & \multicolumn{1}{|c|}{ df2 } & \multicolumn{1}{c|}{ Sig. } \\
\hline 1.482 & 3 & 92 & .225 \\
\hline
\end{tabular}

A population can be categorized homogenous if the $\mathrm{F}$ value is higher than 0.05 . As shown in the table above that the $\mathrm{F}$ value is $1.482>$ 0.05 with the significant (sig) 0.225 . Therefore, it can be said that the research sample population is homogenous.

\section{Hypothesis Testing}

It is for proving the null hypothesis. To determine whether the difference is significant, F-test formula is used. The different between means are shown in the table below. 
Table 24

The General Result of STAD and TMR Strategies

3. Metode * Course

Dependent Variable: Prestasi Belaiar

\begin{tabular}{|c|c|c|c|c|c|}
\hline \multirow[b]{2}{*}{ Metode } & \multirow[b]{2}{*}{ Course } & \multirow[b]{2}{*}{ Mean } & \multirow[b]{2}{*}{ Std. Error } & \multicolumn{2}{|c|}{$95 \%$ Confidence Interval } \\
\hline & & & & Lower Bound & Upper Bound \\
\hline \multirow[t]{2}{*}{ TMR } & Course & 11,500 &, 365 & 10,764 & 12,236 \\
\hline & Non Course & 10,417 & 365 & 9,681 & 11,153 \\
\hline \multirow[t]{2}{*}{ STAD } & Course & 12,750 & ,365 & 12,014 & 13,486 \\
\hline & Non Course & 11,250 & ,365 & 10,514 & 11,986 \\
\hline
\end{tabular}

The results of the analysis above show that: (1) STAD strategy is effective to teach question to the students who take English courses. For this reason, the null hypothesis that says STAD strategy is not effective to teach students who take English course is rejected. (2) STAD strategy is effective to teach question to the students who do not take English courses. For this reason, the null hypothesis that says STAD method is not effective to teach students who do not take an English course is rejected. (3) TMR method is effective to teach question to the students who take an English course. For this reason, the null hypothesis that says TMR strategy is not effective to teach students who take English courses is rejected. (4) TMR strategy is effective to teach question to the students who do not take English courses. For this reason, the null hypothesis that says TMR strategy is not effective to teach students who do not take English courses is rejected. (5) Students who take English course have good score. For this reason, the null hypothesis that says students who take English courses do not have good score is rejected. (6) Students who 
do not take English course have good score. For this reason, the null hypothesis that says students who do not take English courses do not have good score is rejected.

\section{Descriptive statistic}

Table 19

The Result of ANOVA

Tests of Between-Subjects Effects

Dependent Variable: Prestasi Belajar

\begin{tabular}{|l|r|r|r|r|r|r|}
\hline Source & \multicolumn{1}{c|}{$\begin{array}{c}\text { Type III Sum of } \\
\text { Squares }\end{array}$} & df & \multicolumn{1}{c|}{$\begin{array}{c}\text { Mean } \\
\text { Square }\end{array}$} & F & Sig. & \multicolumn{1}{c|}{$\begin{array}{c}\text { Partial Eta } \\
\text { Squared }\end{array}$} \\
\hline Corrected Model & $33,562^{2}$ & 3 & 11,187 & 6,991 &, 001 &, 323 \\
Intercept & 6325,021 & 1 & 6325,021 & 3952,202 &, 000 &, 989 \\
METHOD & 13,021 & 1 & 13,021 & 8,136 &, 007 &, 156 \\
COURSE & 20,021 & 1 & 20,021 & 12,510 &, 001 &, 221 \\
METHOD * COURSE &, 521 & 1 &, 521 &, 325 &, 571 &, 007 \\
Error & 70,417 & 44 & 1,600 & & & \\
Total & 6429,000 & 48 & & & & \\
Corrected Total & 103,979 & 47 & & & & \\
\hline
\end{tabular}

a. $\mathrm{R}$ Squared $=, 323$ (Adjusted R Squared $=, 277$ )

Table above shows the F value for each variable is as follows: (1) $\mathrm{F}$ value or F-test for method is 8.136 with significant 0.007 . Since, sig is $0.007<0.05$. Then, it can be concluded that there is a significant difference between students taught using TMR and STAD strategies. (2) $\mathrm{F}$ value or F-test for taking course is 12.510 with significant (sig) 0.001 . Since, the sig is $0.001<0.05$, then it can be concluded that there is a significant difference between students who took English courses and those who did not. (3) F value or F-test for interaction between method and taking course variables shows 0.325 with sig 0.571 . Since, sig 0.571 
$>0.05$, then the interaction between strategies and taking course variables do not effect the students' achievement.

\section{Conclusions}

The calculation of SPSS shown on the tables of data description, it shows that (1) STAD is effective to teach question to students who take English courses. It shows on the pre-test and post-test result. Before being taught using STAD strategy, the mean score of students who take courses is 10.83 and after being taught is 12.75 . (2) STAD is effective to teach question to students who do not take English courses. It shows on the pre-test and post-test result. Before being taught using STAD strategy, the mean score of students who do not take English courses is 8.58 and after being taught is 11.25. (3) TMR is effective to teach question to students who take English courses. It shows on the pre-test and afte post-test result. Before being taught using TMR strategy, the mean score of students who take courses is 10.67 and after being taught is 11.50. (4) TMR is effective to teach questions to students who do not take English courses. It shows on the pre-test and post-test result. Before being taught using TMR strategy, the mean score of students who do not take courses is 9.83 and after being taught is 10.42. (5) There is a significant different on the questions mastery taught using STAD and TMR strategies. It shows on the result of post-test. The post-test of STAD is 12.00 while TMR is 10.96. (6) There was not any interaction between the students who take English courses and who do not and and who were taught by using STAD and TMR atrategies.it showed from the ANOVA result. The result was the interaction between strategies and taking courses variables showed 0.325 with sig 0.571 . Since, sig $0.571>$ 
0.05 , then the interaction between strategies and taking courses variables do not effect the students achievement.

Based on the data description above, the students' achievement of both STAD and TMR strategies are increasing. It means that STAD and TMR strategies are effective to teach third grade students of SDN Sompok 03 and 04. However, STAD strategy shows better achievement than TMR strategy. It has similar result related to other studies.

The strength points of both strategies are:

(1) The teacher distributes and collects materials for the group. Instead of dealing with 39 students, the teacher was dealing with 7 groups. This saves a lot of time and energy.

(2) Instead of asking the principal for 48 sets of tasks, the writer asks for 7 sets (one for each group). This is a tremendous costs savings.

(3) Students sometimes explain things to each other are better than a teacher can to an entire class of students. This usually results in better retention of material.

(4) Questions are more likely to be asked and answered in a group setting. This saves a lot of time over a long question-and-answer session with the entire class, which can cause some students to become bored.

(5) Students today seem to have a much shorter attention span than they did years ago. With cooperative learning used on regular basis, they are less likely to become restless or misbehave during a teacherdirected part of a lesson since they know they will have time in groups.

(6) Varying from teacher-directed to group-directed activities prevents your class from falling into a rut. 
(7) Shy students are more likely to ask and answer questions in a group setting. The same is true of low-skills students.

A level of a subdivision under STAD and TMR strategies are students who join and students who do not take additional English courses. Both groups showed a significant increase in students' achievement. However, the highest achievement is showed on STAD cases.

This is also related to the ANOVA result on the students interaction between students who take English couses and who do not and who were taught using STAD and TMR strategies. The result was there was no interaction between those variables. The differences on the students' achievement are probably because (1) Some students may not respond well in forced group situations, (2) Students' understanding in course and non-course group is different, and (3) Inappropriate teaching strategy

\section{References}

Heaton, J. B. 1979. Writing English Language Testing.London: Longman Tseng, L. 2005. Understanding Between Teaching and Learning: An Analysis of The contribution of Applied Liguistics. Retrieved on 4 February 2010 from http://www.nrdc,org.uk

Bialkowski, S. 2000. F-test. Utah: Utah State University. Retrieved on 4 February 2010 from http://www.experiment-resources.com/ftest.html\#ixzz0x17HXbi2

Blackwell, M. 2008. Multiple Hypothesis Testing: F-test. Retrieved on 4 February 2010 from http://faculty.vassar.edu/lowry/odds $2 \times 2 . h t m l$

Carol, A. 1998. High School Graduates in Entry Level Jobs: What do employers want? New York: Eric Digest No 40 Reproduction Service No. ED 293972 
Carson, L. 1991. Cooperative Learning in the Economics Classroom. Journal of Home Economics, 82 (4), 37-41

Cohen, L et al. 2007. Research Methods in Education. New York: Routledge

Dinas Pendidikan Kota Semarang. 2008. Kurikulum Bahasa Inggris 2008 untuk SD. Semarang: Departemen Pendidikan Kota Semarang

Dishon, D. \& O' Leary, P. 1984. A Guide Book for Cooperative Learning: a technique for creating more effective schools. Holmes Beach FL: Learning Publication

Goodlad, J. L. 1984. A Place Called School. New York: McGraw Hall

Heaton, J. B. 1979. Writing English Language Testing. London: Longman

Hornby, A. S. 2000. Oxford Advanced Learner's Dictionary. Britain: Oxford University Press. Retrieved on 4 February 2010 from http://www.englishclub.com/vocabulary/wh-question-words.htm

Jacobs, G. M., Power, M. A., Loh, W. I. 2002. The teacher's sourcebook for cooperative learning: Practical techniques, basic principles, and frequently asked questions. Thousand Oaks, CA: Corwin Press. Retrieved on 4 February 2010 from http://www.corwinpress.com/index1.asp?id=detail.asp?id=27713

Johnson, D. W., Johnson, R. T. 1987. Learning Together and Alone: Cooperative, Competitive, and Individualistic Learning. Boston: Allyn \& Bacon.

Johnson, D. W., Johnson, R. T. 1989. Leading the Cooperative School. Edina, MN: Interaction

Johnson, D. W., Johnson, R. T. 1991. Learning Together and Alone: Cooperative, Competitive, and Individualistic Learning ( $3^{\text {th }} \mathrm{ed}$.). Boston: Allyn \& Bacon.

Johnson, D. W., Johnson, R. T., \& Holubec, E. J. 1986. Circles of Learning: Cooperation in The Classroom. Edina, MN: Interaction Book Company

Johnson, D. W., Johnson, R. T., Holubec, E. J. \& Roy, P. 1984. Circles of Learning: Cooperation in The Classroom. Alexandria, VA: Association for Supervision and Curriculum Departement

Slavin, R. E. 2005. Cooperative learning: Theory, research, and practice (2nd ed.). London: Allyman Bacon

Slavin, R. E. 2007. Cooperative learning: Theory, research, and practice (3rd ed.). London: Allyman Bacon 
Tseng, L. 2005. Understanding Between Teaching and Learning: An Analysis of The contribution of Applied Liguistics. Retrieved on 4 February 2010 from

http://www.nrdc,org.uk 
